Article

\title{
New Approach to Fuelization of Herbaceous Lignocelluloses through Simultaneous Saccharification and Fermentation Followed by Photocatalytic Reforming
}

\author{
Masahide Yasuda ${ }^{1{ }^{*}}$, Ryo Kurogi ${ }^{1}$, Hikaru Tsumagari ${ }^{1}$, Tsutomu Shiragami ${ }^{1}$ and \\ Tomoko Matsumoto ${ }^{2}$
}

1 Department of Applied Chemistry, Faculty of Engineering, University of Miyazaki, Gakuen-Kibanadai Nishi, Miyazaki 889-2192, Japan;

E-Mails: tb14010@student.miyazaki-u.ac.jp (R.K.); tb11020@student.miyazaki-u.ac.jp (H.T.); t0g109u@cc.miyazak-u.ac.jp (T.S.)

2 Center for Collaborative Research and Community Cooperation, University of Miyazaki, Gakuen-Kibanadai Nishi, Miyazaki 889-2192, Japan; E-Mail: t-matsu@cc.miyazak-u.ac.jp

* Author to whom correspondence should be addressed; E-Mail: yasuda@cc.miyazak-u.ac.jp; Tel.: +81-985-58-7314; Fax: +81-985-58-7315.

Received: 1 May 2014; in revised form: 13 June 2014 / Accepted: 19 June 2014 /

Published: 26 June 2014

\begin{abstract}
Bio-fuelization of herbaceous lignocelluloses through a simultaneous saccharification and fermentation process (SSF) and photocatalytic reforming (photo-Reform) was examined. The SSF of the alkali-pretreated bamboo, rice straw, and silvergrass was performed in an acetate buffer $(\mathrm{pH} 5.0)$ using cellulase, xylanase, and Saccharomyces cerevisiae at $34{ }^{\circ} \mathrm{C}$. Ethanol was produced in $63 \%-85 \%$ yields, while xylose was produced in 74\%-97\% yields without being fermented because xylose cannot be fermented by $S$. cerevisiae. After the removal of ethanol from the aqueous SSF solution, the SSF solution was subjected to a photo-Reform step where xylose was transformed into hydrogen by a photocatalytic reaction using Pt-loaded $\mathrm{TiO}_{2}$ ( 2 wt \% of Pt content) under irradiation by a high pressure mercury lamp. The photo-Reform process produced hydrogen in nearly a yield of ten theoretical equivalents to xylose. Total energy was recovered as ethanol and hydrogen whose combustion energy was $73.4 \%-91.1 \%$ of that of the alkali-pretreated lignocelluloses (holocellulose).
\end{abstract}


Keywords: bamboo; rice straw; silvergrass; cellulase; xylanase; simultaneous saccharification and fermentation (SSF); hydrogen-evolution; Pt-loaded $\mathrm{TiO}_{2}$

\section{Introduction}

Ethanol production from biomass has been receiving a great amount of interest from the viewpoint of being a renewable energy alternative to petroleum-based fuels [1]. Second generation bioethanol production from lignocellulosic biomass has been recognized as one of the promising approaches, since the lignocelluloses are not directly in competition with food sources [2]. Usual ethanol production from lignocellulose is conveniently achieved by simultaneous saccharification and fermentation (SSF) using Saccharomyces cerevisiae and hydrolytic enzymes [3,4]. However, the ethanol yield is low compared with the first generation bioethanol produced from starches which are composed of glucose units (Equation (1)), because of the high content of hemicellulose composed of xylose units, which are not utilized by $S$. cerevisiae. Therefore fermentation of xylose has been performed using recombinant species of Escherichia coli [5-8] and S. cerevisiae [9-12]. In order to develop a more convenient methodology to utilize xylose, we intend to develop photocatalytic reforming of xylose to hydrogen (Equation (2)) using a Pt-loaded titanium oxide $\left(\mathrm{Pt}-\mathrm{TiO}_{2}\right)$ [13]:

$$
\begin{aligned}
& \mathrm{C}_{6} \mathrm{H}_{2} \mathrm{O}_{6} \underset{\text { S. cerevisiae }}{\longrightarrow} 2 \mathrm{CO}_{2}+2 \mathrm{C}_{2} \mathrm{H}_{5} \mathrm{OH} \\
& \mathrm{C}_{5} \mathrm{H}_{10} \mathrm{O}_{5}+5 \mathrm{H}_{2} \mathrm{O} \underset{\mathrm{Pt}^{-}-\mathrm{hiO}_{2}}{\longrightarrow} 5 \mathrm{CO}_{2}+10 \mathrm{H}_{2}
\end{aligned}
$$

The photocatalytic hydrogen evolution from $\mathrm{H}_{2} \mathrm{O}$ by the $\mathrm{Pt}-\mathrm{TiO}_{2}$ is initiated by the charge-separation on $\mathrm{TiO}_{2}$ under photoexcitation [14]. The electrons reduce water to generate $\mathrm{H}_{2}$ on $\mathrm{Pt}$ while holes oxidize hydroxide to hydroxyl radical. It is well known that the use of electron-donating sacrificial agents remarkably accelerates $\mathrm{TiO}_{2}$-photocatalyzed hydrogen evolution since the hydroxyl radical is consumed by the sacrificial agents [15]. Recently, we have found that sacrificial agents with all of the carbon attached oxygen atoms such as saccharides (e.g., glucose and xylose) and polyalcohols (e.g., 1,2-ethanediol, glycerol, and arabitol) serve as an electron source until their sacrificial ability was exhausted in the $\mathrm{TiO}_{2}$-photocatalytic hydrogen evolution [16]. Therefore, our attention has been focused on the photocatalytic reforming (photo-Reform) of biomasses using $\mathrm{Pt}_{-} \mathrm{TiO}_{2}$ photocatalyst. Here we examined a new approach to fuelization of bamboo, rice straw, and silvergrass through SSF followed by photo-Reform (Scheme 1).

Scheme 1. Conversion of lignocelluloses to hydrogen through SSF followed by photo-Reform. Operation: $A L$ : alkali-pretreatment; $S S F$ : simultaneous saccharification and fermentation; photo-Reform: photocatalytic reforming using a $\mathrm{Pt}-\mathrm{TiO}_{2}$ catalyst.

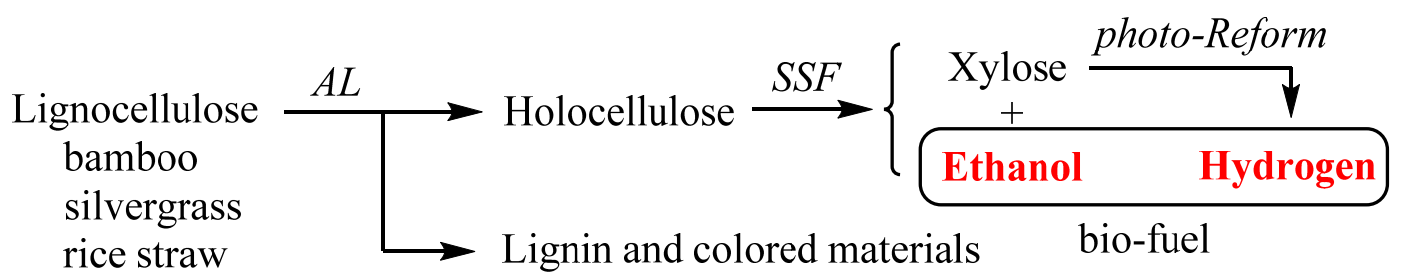




\section{Results and Discussion}

\subsection{SSF Process}

In order to remove colored materials such as lignin and chlorophyll, which disturb the light-absorption of the $\mathrm{Pt}-\mathrm{TiO}_{2}$, the powdered lignocellulose was treated with a $1 \%$ aqueous solution of $\mathrm{NaOH}$ at $95{ }^{\circ} \mathrm{C}$ for $1 \mathrm{~h}$. The colored materials were dissolved in the aqueous $\mathrm{NaOH}$ solution. The holocellulose (a mixture of cellulose and hemicellulose) was isolated as a pale yellow precipitate by centrifugation. After the $\mathrm{pH}$-adjustment to 7.0, the washed holocellulose was collected by centrifugation and dried.

The alkali-pretreated lignocellulose (holocellulose) was converted into ethanol and xylose by SSF which was performed in an acetate buffer solution at $34{ }^{\circ} \mathrm{C}$ using cellulase, xylanase, and the suspension solution of $S$. cerevisiae. The progress of SSF was monitored by the volume of $\mathrm{CO}_{2}$ and continued for 59-144 h until the $\mathrm{CO}_{2}$ evolution ceased. The time-conversion of the $\mathrm{CO}_{2}$-evolution is shown in Figure 1A.

Figure 1. (A) Time-conversion plots of the $\mathrm{CO}_{2}$ evolution in SSF reaction of alkali-pretreated bamboo $(\mathbf{\Delta})$, rice straw $(\triangle)$, and silvergrass $(\bigcirc)$; $(\mathbf{B})$ Typical time-conversion plots of the total gas volume evolved from photo-Reform of xylose which was obtained from SSF of bamboo.
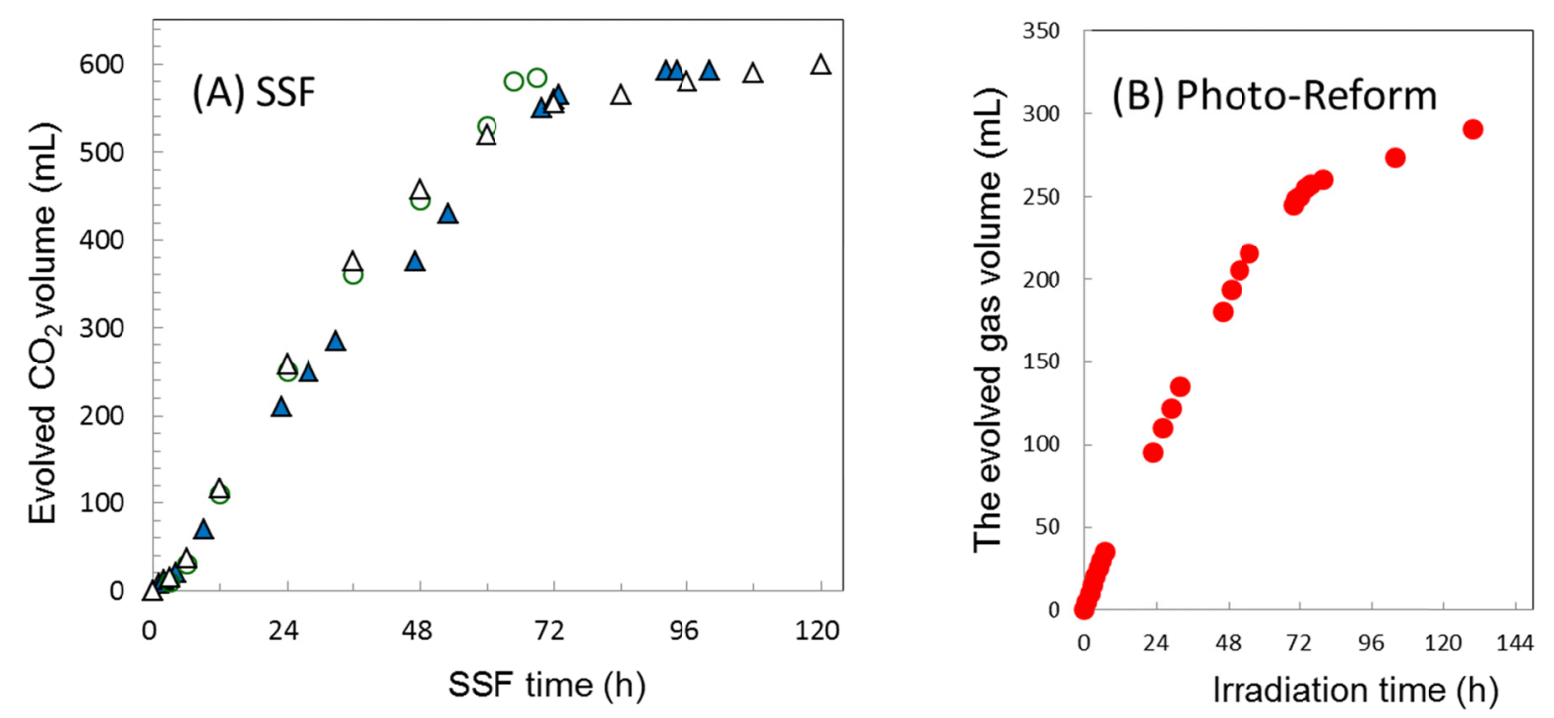

Holocellulose was hydrolyzed to glucose and xylose by a mixture of cellulase and xylanase. We have recently found that the use of xylanase in addition to cellulase accelerates the SSF process of lignocelluloses [17]. Glucose was smoothly fermented to ethanol by $S$. cerevisiae according to Equation (1). However, xylose remained without being fermented by $S$. cerevisiae. Table 1 summarizes the yields of ethanol and xylose in SSF, which were expressed as average of experiments performed three times. Thus, ethanol and xylose were produced in $63 \%-85 \%$ and $74 \%-97 \%$ yields based on the amounts of glucan and xylan in holocellulose listed in Table 1, respectively. Glucose was consumed completely to the point it was not detected in the SSF solution at all. 
Table 1. Production of ethanol and xylose through SSF of lignocelluloses.

\begin{tabular}{|c|c|c|c|c|c|c|}
\hline \multirow[b]{2}{*}{ Lignocellulose } & \multicolumn{3}{|c|}{ Components (wt \%) } & \multicolumn{3}{|c|}{ SSF process ${ }^{(a)}$} \\
\hline & $\begin{array}{l}\text { Holocellulose }^{(b)} \\
\text { (glucan and xylan) }^{\text {glucan }}\end{array}$ & Lignin & Others & $\begin{array}{c}\text { Time } \\
\text { (h) }\end{array}$ & $\begin{array}{l}\text { Ethanol (g) } \\
(\text { yield }(\%)) \\
\end{array}$ & $\begin{array}{l}\text { Xylose (g) } \\
(\text { yield }(\%))\end{array}$ \\
\hline Bamboo & $60.4(35.9,23.9)$ & 17.1 & 22.5 & 72 & $1.29 \pm 0.1(63)$ & $2.02 \pm 0.2(74)$ \\
\hline Rice straw & $39.0(29.5,9.3)$ & 21.3 & 39.7 & 144 & $1.42 \pm 0.0(85)$ & $1.01 \pm 0.1(96)$ \\
\hline Silvergrass & $37.5(28.1,9.5)$ & 23.0 & 39.5 & 59 & $1.21 \pm 0.1(76)$ & $1.00 \pm 0.4(97)$ \\
\hline \multicolumn{7}{|c|}{$\begin{array}{l}\text { (a) The SSF of the holocellulose was performed in a degassed acetate buffer solution }(\mathrm{pH} 5.0,60 \mathrm{~mL}) \text { at } 34{ }^{\circ} \mathrm{C} \\
\text { using the cell suspension of } S \text {. cerevisiae }(1.2 \mathrm{~mL}) \text {, cellulase }(0.60 \mathrm{~g}) \text {, and xylanase }(0.40 \mathrm{~g}) \text {. The amounts of } \\
\text { holocellulose were set to } 6.04 \mathrm{~g}, 3.90 \mathrm{~g} \text {, and } 3.75 \mathrm{~g} \text { for bamboo, rice straw, and silvergrass respectively. } \\
\text { Yields were based on the amounts of glucan and xylan in holocellulose; }{ }^{(b)} \text { Holocellulose was obtained by } \\
\text { the pretreatment of lignocelluloses }(50 \mathrm{~g}) \text { with a } 1 \% \text { aqueous solution of } \mathrm{NaOH}(600 \mathrm{~mL}) \text { at } 95{ }^{\circ} \mathrm{C} \text { for } 1 \mathrm{~h} \text {. } \\
\text { The components of glucan and xylan were analyzed according to NREL method; }{ }^{(c)} \text { The weight of xylose was } \\
\text { represented as } W_{\mathrm{x}} \text {. }\end{array}$} \\
\hline
\end{tabular}

\subsection{Photo-Reform of Xylose}

\subsubsection{Determination of Limiting Mole Amount of Hydrogen Evolved from Photo-Reform}

Ethanol was recovered from the SSF solution by distillation under reduced pressure. The residual xylose in the SSF solution was subjected to the photo-Reform step. Pt- $\mathrm{TiO}_{2}(100 \mathrm{mg}, 1.25 \mathrm{mmol}$, 2 wt $\%$ of Pt) was introduced to the reaction vessel which was attached to the measuring cylinder. The SSF solution was added in reaction vessel so that the amounts of xylose became $0.25(0.35), 0.50$, $0.75,1.00$, and $1.25 \mathrm{mmol}$, and then the volume of the solution was adjusted to $150 \mathrm{~mL}$ by adding water. After the oxygen was purged from the suspension by bubbling it with $\mathrm{N}_{2}$ gas, the irradiation was performed by a high-pressure mercury lamp under vigorous stirring with magnetic stirrer until the gas evolution ceased. Typical time conversion of the evolved gas is shown in Figure 1B.

Table 2 lists that the evolved gas volumes. The evolved gas increased with the increase of xylose. However, the molar ratios of $\mathrm{H}_{2}$ and $\mathrm{CO}_{2}$ to xylose $\left(\mathrm{H}_{2} /\right.$ xylose and $\mathrm{CO}_{2} /$ xylose $)$ were not proportional to the amount of xylose used. Therefore, the $\mathrm{H}_{2} /$ xylose values were plotted against the molar ratio of xylose to catalyst (xylose/catalyst), as shown in Figure 2. As the xylose/catalyst values decreased, the $\mathrm{H}_{2}$ /xylose values increased. The intercept of the plots represents $H_{2}{ }^{\text {max }}$ which is the limiting mole amount of $\mathrm{H}_{2}$ obtained from one mole of xylose at an infinite amount of catalyst. The $\mathrm{H}_{2}{ }^{\text {max }}$ values were nearly equal to the theoretical value (10.0) shown in Equation (2). The slopes of the plots were changed by the use of lignocellulose. It is possible that they would be affected by the amounts of the materials to lower catalytic activity. Also the limiting mole amount of $\mathrm{CO}_{2}\left(\mathrm{CO}_{2}{ }^{\mathrm{max}}\right)$ were nearly equal to the theoretical values (5.0). Moreover, it was confirmed that the $\mathrm{H}_{2}$ evolution from water was small $(2 \mathrm{~mL})$ in the absence of xylose. Other gases such as $\mathrm{CH}_{4}$ and $\mathrm{CO}$ were not observed in the evolved gas. 
Table 2. Photo-Reform using the xylose (1) derived from $\mathrm{SSF}^{\text {(a) }}$.

\begin{tabular}{|c|c|c|c|c|c|c|c|c|c|c|}
\hline \multirow{2}{*}{$\begin{array}{c}1^{(\mathbf{b})} \\
\left(\mathbf{H}_{2}(\mathrm{~g})\right) \\
\end{array}$} & \multirow{2}{*}{$\begin{array}{l}\text { Run } \\
\text { No. }\end{array}$} & \multirow{2}{*}{$\begin{array}{c}1 \text { (mg) } \\
(1 / \text { catalyst) }\end{array}$} & \multirow{2}{*}{$\begin{array}{c}\text { Irradn. } \\
\text { Time (h) }^{(\mathrm{c})}\end{array}$} & \multicolumn{3}{|c|}{ Volume (mL) } & \multicolumn{2}{|c|}{ Molar Ratio } & \multirow{2}{*}{$\begin{array}{l}\mathrm{H}_{2}{ }^{\max (\mathrm{e})} \\
\left(\mathrm{CO}_{2}{ }^{\max }\right)\end{array}$} & \multirow{2}{*}{$\begin{array}{c}\mathrm{H}_{2}(\mathrm{~g})^{(\mathrm{f})} \\
(\text { yield }(\%))\end{array}$} \\
\hline & & & & Total $^{(d)}$ & $\mathbf{H}_{2}$ & $\mathrm{CO}_{2}$ & $\mathrm{H}_{2} / \mathbf{1}$ & $\mathrm{CO}_{2} / 1$ & & \\
\hline \multirow{5}{*}{$\begin{array}{c}\text { From } \\
\text { bamboo } \\
(0.362)\end{array}$} & 1 & $53(0.3)$ & 52 & 110 & 73 & 37 & 9.35 & 4.68 & \multirow{5}{*}{$\begin{array}{l}10.0 \\
(5.0)\end{array}$} & \multirow{5}{*}{$\begin{array}{c}0.269 \\
(74)\end{array}$} \\
\hline & 2 & $75(0.4)$ & 58 & 152 & 101 & 51 & 9.05 & 4.52 & & \\
\hline & 3 & $113(0.6)$ & 100 & 166 & 149 & 74 & 8.87 & 4.40 & & \\
\hline & 4 & $150(0.8)$ & 147 & 230 & 193 & 97 & 8.62 & 4.33 & & \\
\hline & 5 & $188(1.0)$ & 124 & 270 & 216 & 108 & 7.71 & 3.86 & & \\
\hline \multirow{5}{*}{$\begin{array}{c}\text { From } \\
\text { rice straw } \\
(0.141)\end{array}$} & 6 & $38(0.2)$ & 69 & 84 & 56 & 28 & 10.00 & 5.00 & \multirow{5}{*}{$\begin{array}{l}10.1 \\
(5.1)\end{array}$} & \multirow{5}{*}{$\begin{array}{c}0.136 \\
(96)\end{array}$} \\
\hline & 7 & $75(0.4)$ & 74 & 155 & 103 & 52 & 9.20 & 4.64 & & \\
\hline & 8 & $113(0.6)$ & 87 & 230 & 153 & 77 & 9.11 & 4.58 & & \\
\hline & 9 & $150(0.8)$ & 102 & 300 & 200 & 100 & 8.93 & 4.46 & & \\
\hline & 10 & $188(1.0)$ & 130 & 355 & 243 & 122 & 8.68 & 4.36 & & \\
\hline \multirow{5}{*}{$\begin{array}{c}\text { From } \\
\text { silvergrass } \\
(0.139)\end{array}$} & 11 & $38(0.2)$ & 49 & 80 & 53 & 27 & 9.46 & 4.82 & \multirow{5}{*}{$\begin{array}{l}10.1 \\
(5.0)\end{array}$} & \multirow{5}{*}{$\begin{array}{c}0.134 \\
(97)\end{array}$} \\
\hline & 12 & $75(0.4)$ & 58 & 136 & 91 & 45 & 8.13 & 4.02 & & \\
\hline & 13 & $113(0.6)$ & 70 & 170 & 113 & 57 & 6.73 & 3.39 & & \\
\hline & 14 & $150(0.8)$ & 106 & 185 & 123 & 62 & 5.49 & 2.77 & & \\
\hline & 15 & $188(1.0)$ & 155 & 215 & 143 & 72 & 5.11 & 2.57 & & \\
\hline
\end{tabular}

(a) Irradiation was performed for an aqueous solution $(150 \mathrm{~mL})$ containing xylose (1) and $\mathrm{Pt}^{-\mathrm{TiO}_{2}}(100 \mathrm{mg}$, $1.25 \mathrm{mmol}){ }^{(b)}$ The values in the blanket were the theoretical weight of hydrogen $\left(W_{0}\right)$ obtained from $10 \mathrm{~g}$ of non-pretreated lignocelluoses; ${ }^{(c)}$ Irradiation time until $\mathrm{CO}_{2}$ evolution ceased; ${ }^{(d)}$ Total volume of the evolved gas; (e) The $\mathrm{H}_{2}{ }^{\mathrm{max}}$ and $\mathrm{CO}_{2}{ }^{\max }$ were obtained from Figure 2; ${ }^{(\mathrm{f})}$ The weight of $\mathrm{H}_{2}\left(W_{\mathrm{H}}\right)$ was calculated by the multiplication of the $\mathrm{H}_{2}{ }^{\mathrm{max}}$ by the $W_{\mathrm{X}}$, which was the weight of xylose obtained from the SSF listed in Table 1: $W_{\mathrm{H}}=(2 / 150) H_{2}^{\max } \times W_{\mathrm{X}}$. The yields of $\mathrm{H}_{2}=100 \times W_{\mathrm{H}} / W_{0}$.

Figure 2. Plots of $\mathrm{H}_{2} /$ xylose $(\mathbf{O})$ and $\mathrm{CO}_{2}$ /xylose $(\boldsymbol{\Delta})$ against xylose/catalyst: $(\mathbf{A})$ bamboo; (B) rice straw; and $(\mathbf{C})$ silvergrass.

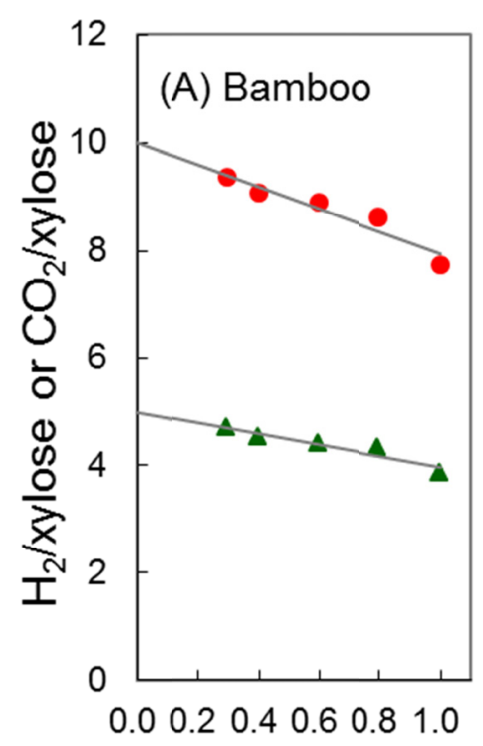

Xylose/catalyst
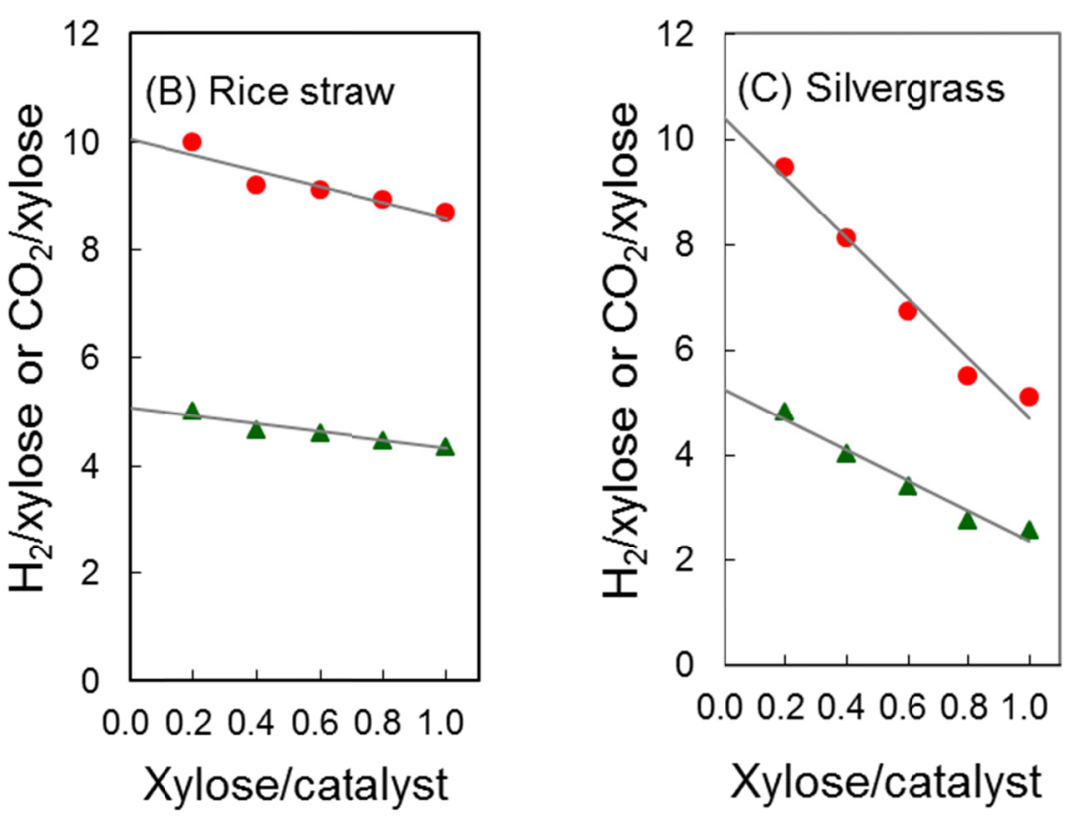
The weight of $\mathrm{H}_{2}\left(W_{\mathrm{H}}\right)$ was calculated by the multiplication of the $H_{2}{ }^{\max }$ by the $W_{\mathrm{X}}$ which was the weight of xylose obtained from the SSF listed in Table 1: $W_{\mathrm{H}}=(2 / 150) H_{2}{ }^{\max } \times W_{\mathrm{X}}$. Thus, the amounts of $\mathrm{H}_{2}$ derived from $10 \mathrm{~g}$ of non-pretreated bamboo, rice straw, and silvergrass were considered to be $0.269 \mathrm{~g}, 0.136 \mathrm{~g}$, and $0.134 \mathrm{~g}$, which corresponded to $74 \%, 96 \%$, and $97 \%$ yield, respectively. Since the hydrogen evolution proceeded quantitatively, these yields for hydrogen evolution were same yields as the xylose yields listed in Table 1.

\subsubsection{Reuse of Photocatalyst}

The Pt- $\mathrm{TiO}_{2}$ was used repeatedly in the photo-Reform in order to check the activity of the photocatalyst. After photo-Reform was performed on $\mathrm{Pt}_{-} \mathrm{TiO}_{2}(1.25 \mathrm{mmol})$ using xylose $(1.25 \mathrm{mmol})$, more xylose ( $1.25 \mathrm{mmol})$ was added in the reaction vessel and irradiated until gas evolution ceased to measure the $\mathrm{H}_{2} /$ xylose values. This operation was repeated eleven times. Figure 3 shows the plots of $\mathrm{H}_{2} /$ xylose against number of repeated cycles using xylose which was obtained from SSF of bamboo (Table 2 run 5). As number of cycle increased, the $\mathrm{H}_{2}$ /xylose gradually decreased from 7.71 to 4.90 , and the irradiation time increased from $124 \mathrm{~h}$ to $174 \mathrm{~h}$. The structure of the $\mathrm{Pt}_{-\mathrm{TiO}_{2}}$ was analyzed by an X-ray diffractometer (Shimadzu XRD 7000). In Figure 4, X-ray diffraction pattern of $\mathrm{Pt}_{-} \mathrm{TiO}_{2}$ catalyst after being used eleven times was compared with that before use. This shows that an anatase structure of $\mathrm{TiO}_{2}$ was kept even after being used in eleven times. Therefore, the materials to lower catalytic activity would be accumulated in the reaction vessel. It is well known that the carboxylic acid can be strongly adsorbed on $\mathrm{TiO}_{2}$. Therefore, it is suggested that the adsorption of carboxylic acid derived from xylose and impurity in SSF solution on $\mathrm{TiO}_{2}$ lowered the photocatalytic activity of Pt- $\mathrm{TiO}_{2}$.

Figure 3. Dependence of the evolved $\mathrm{H}_{2}$ amounts $(\mathrm{O})$ and irradiation time $(+)$ on number of cycles in photo-Reform of xylose obtained from the SSF of bamboo.

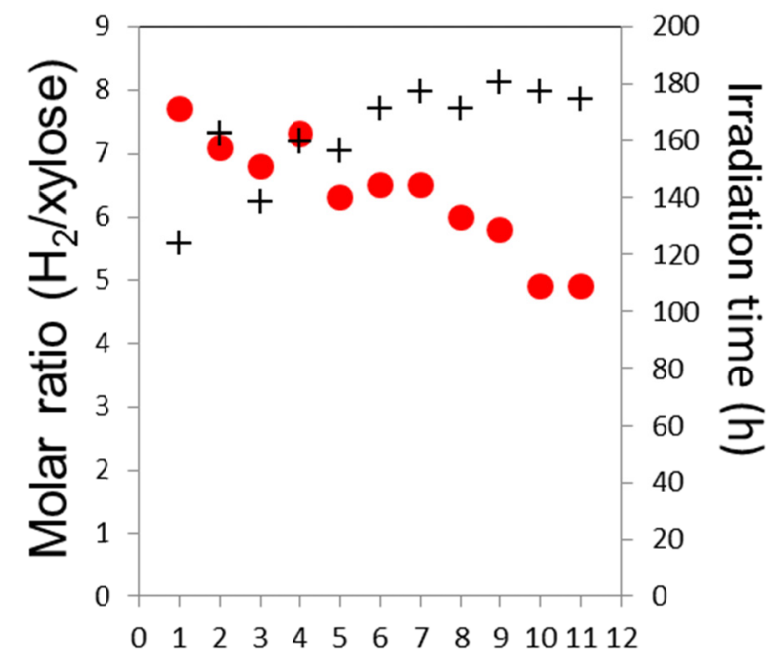

Number of cycles 
Figure 4. X-ray diffraction of Pt-loaded $\mathrm{TiO}_{2}$ of before use (blue line) and after use (red line). The symbol * indicates the peak of Teflon removed from the magnate chip during magnetic stirring.

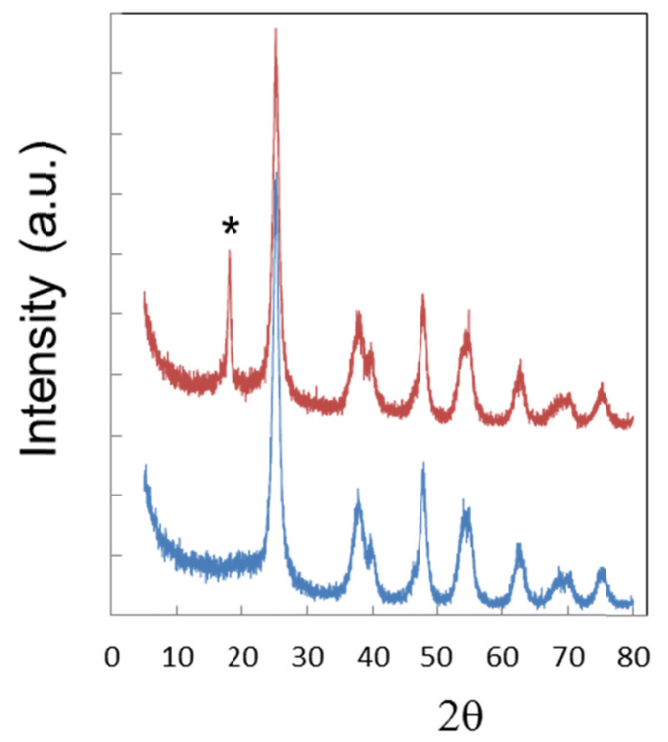

\subsection{Evaluation by Combustion Energy}

Total combustion energy $\left(H_{\mathrm{F}}\right)$ of ethanol and hydrogen [18] produced by SSF and photo-Reform was calculated, as shown in Table 3. Energy recovery efficiency $\left(E_{\mathrm{ff}}\right)$ was calculated by the ratio of $H_{\mathrm{F}}$ to total combustion energy $\left(H_{0}\right)$ of xylose and glucose produced theoretically from $10 \mathrm{~g}$ of the lignocelluloses: $E_{\mathrm{ff}}=100 \times H_{\mathrm{F}} / H_{0}$. The $E_{\mathrm{ff}}$ were considered to be $73.4 \%-91.1 \%$. Since one mole of xylose has the potential to produce ten equivalent of hydrogen (Equation (2)), photo-Reform of xylose can theoretically produce $2850 \mathrm{~kJ}$ of combustion energy of hydrogen which was larger than combustion energy of one mole of xylose $(2336 \mathrm{~kJ})$. Therefore, the energy yields were much higher than the product yields.

Table 3. Comparison between lignocellulose and biofuels in the combustion energy.

\begin{tabular}{|c|c|c|c|c|c|}
\hline \multicolumn{2}{|c|}{ Lignocellulose } & \multicolumn{3}{|c|}{ Biofuels } & \multirow{3}{*}{$E_{\mathrm{ff}}(\%)^{(\mathrm{d})}$} \\
\hline \multirow{2}{*}{\multicolumn{2}{|c|}{$H_{0}(\mathrm{~kJ})\left(W_{\mathrm{G}}, W_{\mathrm{X}}\right)^{(\mathrm{a})}$}} & \multicolumn{2}{|c|}{$H(\mathrm{~kJ}){ }^{(\mathrm{b})}$ (weight $\left.(\mathrm{g})\right)$} & \multirow{3}{*}{$\begin{array}{c}\boldsymbol{H}_{\mathrm{F}}(\mathbf{k J})^{(\mathrm{c})} \\
76.6\end{array}$} & \\
\hline & & $\mathrm{C}_{2} \mathrm{H}_{5} \mathrm{OH}$ & $\mathrm{H}_{2}$ & & \\
\hline Bamboo & $104.5(3.99,2.72)$ & $38.3(1.29)$ & $38.3(0.269)$ & & 73.4 \\
\hline Rice straw & $67.6(3.28,1.06)$ & $42.2(1.42)$ & $19.4(0.136)$ & 61.6 & 91.1 \\
\hline Silvergrass & $64.8(3.12,1.04)$ & $36.0(1.21)$ & $19.1(0.134)$ & 55.1 & 85.0 \\
\hline
\end{tabular}

(a) The total combustion energies $\left(H_{0}\right)$ of xylose and glucose contained in $10 \mathrm{~g}$ of the lignocelluloses were calculated according to the following equation: $H_{0}=2803 \times W_{\mathrm{G}} / 180+2342 \times W_{\mathrm{X}} / 150$ where $W_{\mathrm{G}}$ and $W_{\mathrm{X}}$ were the weights of glucose and xylose in $\mathrm{g}$. The combustion energies for glucose and xylose were $2803 \mathrm{~kJ} \mathrm{~mol}^{-1}$ and $2342 \mathrm{~kJ} \mathrm{~mol}^{-1}$, respectively; ${ }^{(\mathrm{b})}$ Combustion energy $(H)$; ${ }^{(\mathrm{c})}$ Total combustion energy $\left(H_{\mathrm{F}}\right)$ of ethanol and hydrogen. The combustion energies of ethanol and hydrogen were $1367 \mathrm{~kJ} \mathrm{~mol}^{-1}$ and $285 \mathrm{~kJ} \mathrm{~mol}^{-1}$, respectively; ${ }^{(\mathrm{d})}$ Energy recovery efficiency $\left(E_{\mathrm{ff}}\right)=100 \times H_{\mathrm{F}} / H_{0}$. 


\section{Materials and Methods}

\subsection{Chemical Components of Lignocellulose}

First, lignocelluloses were cut, dried, and made into a powder by a blender until the powder passed through a sieve with $150 \mu \mathrm{m}$ mesh. The powdered lignocellulose ( $30 \mathrm{~g})$ was treated with a $1 \%$ aqueous solution of $\mathrm{NaOH}(400 \mathrm{~mL})$ at $95{ }^{\circ} \mathrm{C}$ for $1 \mathrm{~h}$. The holocellulose was isolated as a pale yellow precipitate from the treated mixture by centrifugation at $10,000 \mathrm{rpm}$ for $10 \mathrm{~min}$ and filtration. The supernatant solution was neutralized to $\mathrm{pH} 5.0$ by a dilute $\mathrm{HCl}$ solution. The resulting dark brown precipitate, which was identified as lignin, was collected by centrifugation at 10,000 rpm for $10 \mathrm{~min}$. Saccharides in the holocellulose were determined according to the methods published by the National Renewable Energy Laboratory (NREL) [19] as follows: sulfuric acid (72 wt \%, $3.0 \mathrm{~mL}$ ) was added slowly to holocellulose $(300 \mathrm{mg})$ and kept at $30^{\circ} \mathrm{C}$ for $1 \mathrm{~h}$. The resulting solution was diluted by water $(84 \mathrm{~mL})$ until the concentration of sulfuric acid was $4 \mathrm{wt} \%$. Acid hydrolysis was performed by autoclaving at $121{ }^{\circ} \mathrm{C}$ for $1 \mathrm{~h}$. After the neutralization by $\mathrm{CaCO}_{3}$, the solution was subjected to a centrifugation to give the supernatant solution (ca. $87 \mathrm{~mL}$ ), which was concentrated to $30 \mathrm{~mL}$ by evaporation. The solution was analyzed by HPLC. The peaks of glucose and xylose appeared whereas the peaks of galactose and arabinose were very weak. The amounts of glucan and xylan were determined from the amounts of glucose and xylose determined by HPLC. It was confirmed that the total amounts of glucan and xylan were equal to the amounts of holocellolose. The ash component in lignocellulose was obtained by burning lignocellulose $(2.0 \mathrm{~g})$ in an electric furnace (KBF784N1, Koyo, Nara, Japan) for $2 \mathrm{~h}$ at $850^{\circ} \mathrm{C}$. Thus, the chemical components of lignocelluloses were determined, as shown in Table 1.

\subsection{Hydrolytic Enzyme and Preparation of the Inoculum Culture of S. cerevisiae}

A cellulase from Acremonium cellulolyticus (Acremozyme KM, Kyowa Kasei, Osaka, Japan) was used $[3,20]$. The cellulase activity of Acremozyme was determined to be $1320 \mathrm{units} / \mathrm{mg}$ by the method of breaking down filter paper [20]. A xylanases from Trichoderma longibrachiatum (reesei) (Sumizyme X, Shin Nihon Chemicals, Anjyo, Japan, $5000 \mathrm{u} / \mathrm{g}$ ) was selected from commercially available hemicellulase. S. cerevisiae NBRC 2044 was cultured at $30{ }^{\circ} \mathrm{C}$ for $24 \mathrm{~h}$ in a basal medium (initial $\mathrm{pH}$ 5.5) consisting of glucose $\left(20 \mathrm{~g} \cdot \mathrm{L}^{-1}\right)$, bactotryptone $\left(1.0 \mathrm{~g} \cdot \mathrm{L}^{-1}\right.$, Difco, Leeuwarden, The Netherlands), yeast extract $\left(1 \mathrm{~g} \cdot \mathrm{L}^{-1}\right), \mathrm{NaHPO}_{4}\left(1 \mathrm{~g} \cdot \mathrm{L}^{-1}\right)$, and $\mathrm{MgSO}_{4}\left(3 \mathrm{~g} \cdot \mathrm{L}^{-1}\right)$ [20]. After incubating for $24 \mathrm{~h}$, the cell suspension solution of $S$. cerevisiae was obtained to use in SSF process.

\subsection{Procedures of SSF}

The SSF was performed using the apparatus shown in Figure 5A. A cellulosic material and buffer solution $(37.5 \mathrm{~mL})$ were introduced in the reaction vessel and then autoclaved at $121{ }^{\circ} \mathrm{C}$ for $20 \mathrm{~min}$. After cooling to room temperature under UV-irradiation, the hydrolytic enzyme dissolved in an acetate buffer solution $(22.5 \mathrm{~mL})$ and the cell suspension of $S$. cerevisiae were added to the suspension of the cellulosic material. The holocelluloses from the bamboo, rice straw, and silvergrass were set to $6.04 \mathrm{~g}$, $3.90 \mathrm{~g}$, and $3.75 \mathrm{~g}$, respectively, which corresponded to the amounts of holocellulose in $10 \mathrm{~g}$ of the non-treated lignocellulose. After the air was purged with $\mathrm{N}_{2}$, the SSF was initiated by stirring the 
solution vigorously with a magnetic stirrer at an optimal temperature of $34{ }^{\circ} \mathrm{C}$. The evolved $\mathrm{CO}_{2}$ was collected over water by a measuring cylinder, and the reaction was monitored by the volume of $\mathrm{CO}_{2}$. The amounts of hexose and pentose were analyzed by a Shimadzu LC-20AD (Kyoto, Japan) high-performance liquid chromatography system using anion exchange column (Shodex Asahipak NH2P-50 4E, Tokyo, Japan). Ethanol concentrations were determined by a Shimadzu GC-2014 gas chromatograph using a glass column of 5\% Thermon 1000 on Sunpak-A (Shimadzu, Kyoto, Japan) with 2-propanol as an internal standard.

Figure 5. The apparatus for (A) SSF and (B) photo-Reform.
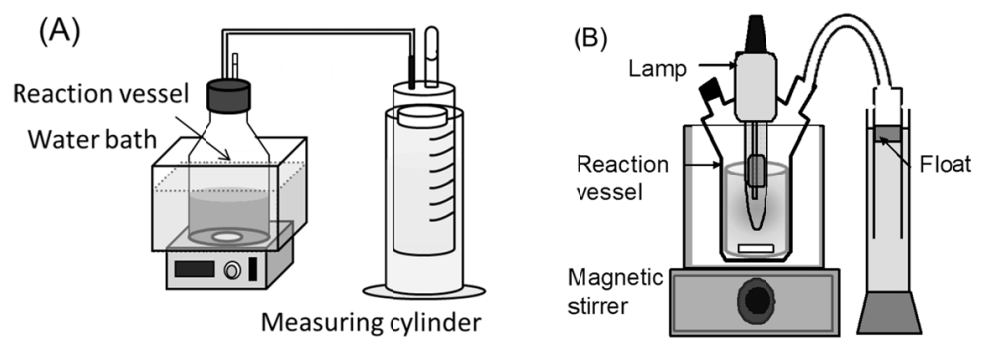

\subsection{Procedures of Photo-Reform}

The photo-Reform was performed as follows. The $\mathrm{Pt}_{-} \mathrm{TiO}_{2}(100 \mathrm{mg})$ and the supernatant solution of xylose $(0.25-1.25 \mathrm{mmol})$ were introduced into the reaction vessel, which was attached to a measuring cylinder with a gas-impermeable tube to collect the evolved gas (Figure 5B). After that, the volume of the solution was adjusted to $150 \mathrm{~mL}$ by adding water, and a high-pressure mercury lamp (100 W, UVL-100HA, Riko, Funabashi, Japan) was inserted into the reaction vessel. The reaction vessel was set in a water bath to keep it at a constant temperature (usually $20^{\circ} \mathrm{C}$ ). After the $\mathrm{O}_{2}$ was purged from the reaction vessel by $\mathrm{N}_{2}$ gas, irradiation was performed while being vigorously stirred with a magnetic stirrer. The evolved gas was collected by the measuring cylinder to measure the volume of the evolved gas. The evolved gas was analyzed on a Shimadzu GC-8A equipped with a TCD detector at a temperature raised from $40{ }^{\circ} \mathrm{C}$ to $180{ }^{\circ} \mathrm{C}$ using a stainless column $(\Phi 3 \mathrm{~mm} \times 6 \mathrm{~m})$ packed with a SHINCARBON $\mathrm{ST}$ (Shimadzu). $\mathrm{H}_{2}$ and $\mathrm{CO}_{2}$ were detected in addition to $\mathrm{N}_{2}$ which was used as the purging gas.

\subsection{Preparation of Photocatalyst}

An anatase-type of $\mathrm{TiO}_{2}$ (ST-01) was purchased from Ishihara Sangyo Kasei Ltd, Osaka, Japan. According to previous research [21], the $\mathrm{Pt}-\mathrm{TiO}_{2}$ was prepared by irradiation of a deaerated aqueous solution $(400 \mathrm{~mL})$ containing $\mathrm{TiO}_{2}(4.0 \mathrm{~g}), \mathrm{K}_{2} \mathrm{PtCl}_{6}(20-200 \mathrm{mg})$, and 2-propanol $(2.4 \mathrm{~g}, 3.0 \mathrm{~mL})$ by a high-pressure mercury lamp for $24 \mathrm{~h}$ under stirring. Water was entirely removed from the photolysate by an evaporator. The resulting precipitate was washed with water on a filter and then dried under reduced pressure to produce the $\mathrm{Pt}-\mathrm{TiO}_{2}$. In our previous study, the optimized Pt-content of $\mathrm{TiO}_{2}$ was determined to be $2.0 \mathrm{wt} \%$ [16].

\section{Conclusions}

The SSF process poses an advantage in ethanol-production from the standpoint of simplicity of the manufacturing process. The present study showed that xylose derived from SSF of lignocellulose 
could be efficiently transformed into hydrogen. The formed bio-fuel, ethanol and hydrogen, has almost the same combustion energy as the saccharide occurring in lignocelluloses. If the UV light in sunlight is used as the light source for catalytic reaction, this will provide a useful method to produce $\mathrm{H}_{2}$ from biomass.

\section{Acknowledgments}

This study was partially supported by a Grant-in-Aid for Scientific Research (C) No. 24610055 from the Ministry of Education, Culture, Sports, Science, and Technology of Japan.

\section{Author Contributions}

Masahide Yasuda conceived experimental idea and analyzed experimental data. Also Masahide Yasuda prepared the manuscript and revised it. Ryo Kurogi carried out SSF and photo-Reform. Hikaru Tsumagari carried out the preparation of Pt-loaded $\mathrm{TiO}_{2}$ catalyst as well as photo-Reform using catalyst repeatedly used under supervision of Tsutomu Shiragami. Tomoko Matsumoto carried out a measurement of an X-ray diffraction.

\section{Conflicts of Interest}

The authors declare no conflict of interest.

\section{References}

1. Ward, O.P.; Singh, A. Bioethanol technology: Development and perspectives. Adv. Appl. Microbiol. 2002, 51, 53-80.

2. Balat, M.; Balat, H. Recent trends in global production and utilization of bio-ethanol fuel. Appl. Energy 2009, 86, 2273-2282.

3. Yasuda, M.; Miura, A.; Yuki, R.; Nakamura, Y.; Shiragami, T.; Ishii, Y.; Yokoi, H. The effect of $\mathrm{TiO}_{2}$-photocatalytic pretreatment on the biological production of ethanol from lignocelluloses. J. Photochem. Photobiol. A 2011, 220, 195-199.

4. Shiragami, T.; Tomo, T.; Tsumagari, H.; Ishii, Y.; Yasuda, M. Hydrogen evolution from napiergrass by the combination of biological treatment and a Pt-loaded $\mathrm{TiO}_{2}$-photocatalytic reaction. Catalyst 2012, 2, 56-67.

5. Ohta, K.; Alterthum, F.; Ingram, L.O. Effects of environmental conditions on xylose fermentation by recombinant Escherichia coli. Appl. Environ. Microbiol. 1990, 56, 463-465.

6. Ohta, K.; Beall, D.S.; Mejia, J.P.; Shanmugam, K.T.; Ingram, L.O. Genetic improvement of Escherichia coli for ethanol production: Chromosomal integration of Zymomonas mobilis genes encoding pyruvate decarboxylase and alcohol dehydrogenase II. Appl. Environ. Microbiol. 1991, 57, 893-900.

7. Underwood, S.A.; Buszko, M.L.; Shanmugam, K.T.; Ingram, L.O. Flux through citrate synthase limits the growth of ethanologenic Escherichia coli KO11 during xylose fermentation. Appl. Environ. Microbiol. 2002, 68, 1071-1081. 
8. Brandon, S.K.; Sharma, L.N.; Hawkins, G.M.; Anderson, W.F.; Chambliss, C.K.; Doran-Peterson, J. Ethanol and co-product generation from pressurized batch hot water pretreated T85 bermudagrass and Merkeron napiergrass using recombinant Escherichia coli as biocatalyst. Biomass Bioenerg. 2011, 35, 3667-3673.

9. Jin, M.; Gunawan, C.; Balan, V.; Lau, M.W.; Dale, B.E. Simultaneous saccharification and co-fermentation (SSF) of $\mathrm{AFEX}^{\mathrm{TM}}$ pretreated corn stover for ethanol production using commercial enzymes and Saccharimyces cerevisiae 424A (LNH-ST). Bioresouce Technol. 2012, 110, 587-594.

10. Jin, M.; Gunawan, C.; Balan, V.; Yu, X.; Dale, B.E. Continuous SSF and AFEX ${ }^{\mathrm{TM}}$ pretreated corn stover for enhanced ethanol productivity using commercial enzymes and Saccharimyces cerevisiae 424A (LNH-ST). Biotechnol. Bioeng. 2012, 110, 1302-1311.

11. Ohgren, K.; Bengtsson, O.; Gorwa-Grauslund, M.F.; Galbe, M.; Hahn-Hagerdal, B.; Zacchi, G. Simultaneous saccharification and co-fermentation of glucose and xylose in steam-pretreated corn stover at high fiber content with Saccharomyces cerevisiae TMB3400. J. Biotechnol. 2006, 126, 488-498

12. Matsushika, A.; Inoue, H.; Kodaki, T.; Sawayama, S. Ethanol production from xylose in engineered Saccharomyces cerevisiae strains: current state and perspectives. Appl. Micorobiol. Biotechnol. 2009, 84, 37-53.

13. Shiragami, T.; Tomo, T.; Tsumagari, H.; Yuki, R.; Yamashita, T.; Yasuda, M. Pentose acting as a sacrificial multi-electron source in photocatalytic hydrogen evolution from water by Pt-doped $\mathrm{TiO}_{2}$. Chem. Lett. 2012, 41, 29-30.

14. Fujishima, A.; Rao, T.N.; Tryk, D.A. Titanium dioxide photocatalysis. J. Photochem. Photobiol. C Rev. 2000, 1, 1-21.

15. Galinska, A.; Walendziewski, J. Photocatalytic water splitting over $\mathrm{Pt}-\mathrm{TiO}_{2}$ in the presence of sacrificial reagents. Energy Fuels 2005, 19, 1143-1147.

16. Shiragami, T.; Tomo, T.; Matsumoto, T.; Yasuda, M. Structural dependence of alcoholic sacrificial agents on $\mathrm{TiO}_{2}$-photocatalytic hydrogen evolution. Bull. Chem. Soc. Jpn. 2013, 86, 382-389.

17. Yasuda, M.; Takeo, K.; Nagai, H.; Uto, T.; Yui, T.; Matsumoto, T.; Ishii, Y.; Ohta, K. Enhancement of ethanol production from napiergrass (Pennisetum purpureum Schumach) by a low-moisture anhydrous ammonia pretreatment. J. Sustain. Bioenergy Syst. 2013, 3, 179-185.

18. Atkins, P.W. Physical Chemistry, 5th ed.; Oxford University Press: Oxford, UK, 1994; pp. 922-926.

19. Sluiter, A.; Hames, B.; Ruiz, R.; Scarlata, C.; Sluiter, J.; Templaton, D.; Crocker, D. Determination of Structural Carbohydrates and Lignin in Biomass; Technical Report; NREL/TP-510-42618; National Renewable Energy Laboratory: Golden, CO, USA, 2010.

20. Yasuda, M.; Miura, A.; Shiragami, T.; Matsumoto, J.; Kamei, I.; Ishii, Y.; Ohta, K. Ethanol production from non-pretreated napiergrass through a simultaneous saccharification and fermentation process followed by a pentose fermentation with Escherichia coli KO11. J. Biosci. Bioeng. 2012, 114, 188-192.

21. Kennedy, J.C., III; Datye, A.K. Photochemical heterogeneous oxidation of ethanol over Pt/TiO 2 . J. Catal. 1998, 179, 375-389.

(C) 2014 by the authors; licensee MDPI, Basel, Switzerland. This article is an open access article distributed under the terms and conditions of the Creative Commons Attribution license (http://creativecommons.org/licenses/by/3.0/). 